\title{
Medical genetics around the world
}

Journal of Medical Genetics 1989, 26, 179-189

\section{Medical genetics in Israel}

R M GOODMAN*†, B BONNE-TAMIR $\dagger$, A ADAM , R VOSS ${ }^{* *}$, G BACH§, Y SHILOH $\dagger$, M BAT-MIRIAMKATZNELSON* ${ }^{*}$, G BARKAI ${ }^{*} \dagger$, B GOLDMAN ${ }^{*} \dagger$, B PADEH* $\dagger$, J CHEMKE $₫ \|$, AND C LEGUM $\uparrow \rrbracket$

From *the Institute of Medical Genetics, The Chaim Sheba Hospital; †Department of Human Genetics, Sackler School of Medicine, Tel-Aviv University; $¥$ Department of Biology, Everyman’s University; §Department of Human Genetics, Hadassah University Hospital, Hebrew University; |Kaplan Hospital, Rehovot; and ØIchilov Hospital, Tel-Aviv, Israel.

When I was asked to write this article on human genetics in Israel, I was pleased to accept the challenge, but after pondering the subject for a period of time, I began to see some of the difficulties in such an undertaking, owing to the great amoutit of investigative studies that has taken place in our country. My major concern was the unintentional omission of important historical information along with scientific contributions to this broad and rapidly advancing field. I decided that the best way to handle this problem would be to call upon certain of my colleagues and ask them to write on the development and progress in their special areas. Despite all of our combined efforts I am certain that omissions must have occurred, but we hope that understanding will prevail and that time and space will also be taken into consideration.

As this paper was nearing completion one of our key contributors, Dr Ruth Voss of the Hadassah University Hospital of the Hebrew University, suddenly died in a tragic car accident. Because she was such an outstanding person as well as a human cytogeneticist, we would like to dedicate this article to her blessed memory.

\section{Historical background}

Matters of genetic concern have been an integral part of Jewish life dating from the Biblical period. In the Torah (first five books of Moses) book of Genesis (chapter 30, lines 32-43) one can find a written account of Jacob's breeding experiments with his father in law's sheep and goats. In the book of Leviticus (chapter 18, lines 6-18) one will find

**Deceased.

Received for publication 23 September 1988.

Accepted for publication 30 September 1988. specific laws stating whom one can and cannot marry. The Babylonian Talmud compiled approximately 1500 years ago is an extremely rich source for the description of a number of human genetic malformations and syndromes. ${ }^{1}$ For example, various cranial, facial, and body malformations are mentioned in Kodashim, tractate Bekhorot 44a, familial epilepsy is described in Nashim, tractate Yevamot $64 \mathrm{~b}$, and in the same tractate and page one can find a report of haemophilia. The testicular feminisation syndrome can be recognised from the writing and discussion found in Nashim, tractate Ketuboth 10b, and a clinical description of Marfan's syndrome is mentioned in Kodashim, tractate Bekhorot 45b. Analysis of the Talmud for genetic malformations and syndromes is in its infancy and in the years to come such studies should prove most rewarding.

With a long Jewish tradition of critical thinking about all matters pertaining to life, coupled with the newly emerging interest in human genetics, it was not surprising that the modern State of Israel, established in 1948, would find itself actively engaged in a variety of human genetic studies. The main impetus for this initial flourish of activity came from the massive number of Jewish immigrants arriving in Israel from all parts of the world. Israel immediately became the ideal setting for studying genetic similarities and differences among the Jewish people. In addition to investigating genetic polymorphisms among the various Jewish communities, Israeli physicians and geneticists also found themselves absorbed in learning about such inherited diseases as familial Mediterranean fever, Dubin-Johnson syndrome, G6PD deficiency, thalassaemia, and phenylketonuria to mention just a few.

Although several medical centres and institutions soon became interested in the practical and investigative aspects of genetic diseases and polymorph- 
isms among the Jewish people, two centres in particular achieved international recognition for their pioneering work in these areas. The Hadassah University Hospital and the Hebrew University in Jerusalem under the guidance of the late Professor Elizabeth Goldschmidt, and the former TelHashomer Hospital (now the Chaim Sheba Medical Centre) and the Tel-Aviv University under the inspiration and thinking of the late Professor Chaim Sheba became the leading medical genetic centres in Israel.

\section{Israel and its people}

Israel is a very small country, approximately 280 miles $(450 \mathrm{~km})$ in length and 110 miles $(180 \mathrm{~km})$ at maximum width. The majority of its total population of approximately 5 million people is clustered in the centre of the country. Seventy-five percent of its land is desert. The population can be divided into Jewish (4.3 million) and non-Jewish (700 000), mainly Arab-Moslems. The Jewish population can similarly be grouped into three major ethnic groups. ${ }^{2}$ The oldest are the Oriental Jews (originating from the continent of Asia), followed by the Sephardi Jews (originating from countries of the Mediterranean basin), which together comprise $53 \%$ of the Jewish Israeli population. The youngest of the groups, the Ashkenazi Jews (originating from central and eastern Europe), make up the remaining $47 \%$ of the Jewish population. This almost equal distribution between non-Ashkenazi (Oriental plus Sephardi Jews) and Ashkenazi Jews makes the Israeli scene an ideal place to study all genetic aspects of the Jewish people.

\section{Human population genetics}

The initial stimulus for genetic studies among the various Jewish ethnic groups in Israel was the immigration in the early 1950 s of over a million Jewish immigrants making 'aliyah' (literally: coming to Israel from over 100 countries in all continents). It was soon recognised that frequencies of genetic diseases differed markedly among the various communities, an observation which further served as a catalyst for studying the 'genetic profiles' of these populations. ${ }^{34}$ It therefore seems fitting that this report begins with Israeli studies in population genetics. The questions asked initially were essentially those that are being asked today by Israeli population geneticists regarding the Jewish people.

(1) How heterogeneous are each of the communities?

(2) How much do they differ genetically from each other and from their previous host population?
(3) To what extent do the genetic data correlate with known or surmised histories of the various groups?

(4) What can studies of genealogies, mating preferences, and inbreeding patterns tell us about the extent of genetic isolation of Jewish communities and the directions of gene flow?

Over the years, the tools and methods of human population studies have changed considerably. In the beginning, Israeli geneticists, like their colleagues elsewhere, characterised and compared Jewish ethnic groups by using frequencies of genetic markers such as blood groups, serum proteins, isozymes, colour vision deficiencies, taste sensitivity to PTC, finger and palm print analyses, as well as morphological and anthropometric measurements. ${ }^{4}$ While the early studies in the 1950s and 1960s emphasised the differences rather than the similarities between the Jewish communities, some of the more recent studies point to a basic genetic similarity, particularly regarding blood group polymorphisms, and to the small contribution of non-Jews to the Jewish gene pool. In the 1970s, studies using the histocompatibility antigens (HLA system) provided new data allowing renewed examination of the historical-geographical groupings of Jewish exiles. ${ }^{5-8}$ Findings indicated elements of a common origin for most of the major Jewish ethnic groups, as well as an absence of substantial gene influx from non-Jewish populations into the Jewish gene pool. Previous thinking that Jews of any given area tend to resemble the non-Jews of that area more closely than they do one another was not substantiated by the abundant polymorphic data accumulated, nor by the recognition of an increasing number of specific Jewish genetic diseases.

Furthermore, multivariate statistical methods such as estimates of genetic distances or cluster analysis, based on a large number of genetic loci, supported the contention that not much admixture had taken place between European Jews (Ashkenazi) and their gentile neighbours. ${ }^{6} 79$

Also some Oriental Jews, like those from Iraq, have genetically far more in common with Ashkenazi Jews (central and east European Jews) than either group has with the non-Jews among whom they have lived for centuries.

As one might expect, there are also exceptions to this overall picture of relative Jewish distinctiveness. Jews from Yemen are a case in point; they have a genetic make up that is characteristic of the Arabian peninsula which probably indicates a massive genetic contribution into the small pre-existing Jewish community from indigenous tribes who converted to Judaism in the fourth or fifth centuries. A similar situation exists with regard to Cochin Jews ${ }^{10} 11$ and

\section{.} $\omega$ वे .

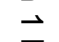
금

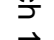

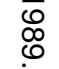


local Kerala Indians and with regard to the Ethiopian Jews ${ }^{12}$ and the non-Jewish Ethiopian tribes. Thus these Jewish communities are genetically linked to their non-Jewish 'hosts' and have little in common with other Oriental, Sephardi, or Ashkenazi Jewish groups.

Present efforts of population genetic studies in Israel aim to scrutinise genetic variation at the molecular level and to re-examine genetic diversity among the ethnic communities using DNA polymorphisms. Results of restriction endonuclease fragment patterns in mitochondrial DNA which have been investigated in several Israeli groups tend to support conclusions drawn earlier regarding the similarity between European and North African Jews. ${ }^{13}$ On the other hand, mtDNA in Yemenite and Ethiopian Jews demonstrates unique and group specific patterns which reflect their isolation.

Before concluding this section, it is worthwhile to point out that Israeli population geneticists have also directed considerable effort to studying various non-Jewish ethnic groups in the country, such as Arabs, Armenians, Druze, and Circassians. Perhaps the two most extensive studies of non-Jews that have been done are on the Samaritans, a unique religious sect and isolate of about 500 members, tracing their origins back to the ancient Israelites, ${ }^{14}$ and on the Bedouin tribes of South Sinai.

\section{Clinical genetics}

In the 1950s few physicians thought much about the role of genetic factors influencing disease. However, in Israel during these years, with the influx of thousands of Jews into the country from all parts of the world, Israeli physicians found themselves confronted with patients with symptoms and findings unfamiliar to them. The fact that they observed similar and often identical features in other family members stimulated them to think in terms of a possible genetic aetiology for the disorders in question. The frequent presence of close parental consanguinity coupled with affected sibs became the genetic hallmark for a number of newly recognised autosomal recessive diseases in the Sephardi and Oriental Jewish communities in Israel. ${ }^{15}$ Genetic disorders among the Ashkenazi community for the most part had been either previously described elsewhere, or were later to be recognised within the Ashkenazi communities of Israel and the United States. ${ }^{16}$ Thus, Israel's major contribution to the clinical recognition and description of genetic disorders among the Jewish people involves mainly those conditions which affect the non-Ashkenazi communities (Oriental and Sephardi Jews). This is understandable as the Ashkenazi community (83\% of world Jewry) is concentrated mainly in the western world where the level of investigative medicine is the highest. Within a relatively short period of time (approximately 10 years) the Jewish communities in Israel could be characterised by those genetic diseases having a high frequency in the various ethnic groups.

The approach to investigating these disorders was basically a multidisciplinary one and involved not only the team efforts of Israeli geneticists, biochemists, and clinicians, but also international talent as well. Those who were part of these teams cherish the memories that these investigative studies evoked in terms of splendid cooperation and scientific excitement.

By the year 1962 such an enormous wealth of genetic information on diseases and polymorphisms in Israeli Jews had been amassed that the late Professor Goldschmidt organised an international conference held in Jerusalem and entitled The genetics of migrant and isolate populations. ${ }^{3}$ Eleven years later an update conference entitled Genetic polymorphisms and diseases in $\mathrm{man}^{4}$ was organised in Tel-Aviv to honour the passing of the late Professor Chaim Sheba.

As one would expect, time and scientific advances have changed the direction of clinical genetics in Israel. New genetic diseases and rare syndromes are still being recognised, mainly in the non-Ashkenazi communities, but at a much slower pace. However, there is still much to learn about genetic disorders among Israel's non-Jewish groups and this is being evaluated slowly.

Today in Israel, clinical geneticists are teaming up with molecular geneticists for purposes of linkage studies, prenatal diagnosis, gene mapping, gene cloning, and eventually treatment of genetic diseases. In addition, we are interested in investigating a number of genetic syndromes for their phenotypic heterogeneity, and then having our colleagues in molecular genetics evaluate the degree of heterogeneity existing at the molecular level. As in other countries, clinical geneticists play a key role in the diagnosis of genetic disorders, providing genetic counselling and actively participating in prenatal diagnosis. Almost all major medical centres in Israel have one or more clinical geneticists, and although a well defined training programme in clinical genetics has not yet been established in Israel, this will undoubtedly be organised in the very near future. A one year fellowship programme in Jewish genetic diseases has been established at the Sheba Medical Centre and its first fellow began her studies in the autumn of 1988. Several Israeli physicians, after completing their speciality training, have been sent abroad for training in clinical genetics. Despite all of 
our efforts to maintain an adequate number of people in clinical genetics, there is still a dire need for more.

\section{Cytogenetics}

The basis for the development of human cytogenetics in Israel was the group created at the Hebrew University in Jerusalem by Professor Jacob Wahrman. His experience in mammalian cytogenetics ${ }^{17}$ has been extremely important in the studies of one more mammal, namely Homo sapiens, at the cytogenetic level. In February 1958, the first human material was obtained. This was testicular tissue which yielded meiotic cells of good quality. The development of methods for processing peripheral blood for chromosome studies of mitotic cells enabled the start of cytogenetic studies for medical purposes and contributed to the role of chromosome aberrations in the aetiology of congenital malformation syndromes. ${ }^{18-20}$

With the increasing demand for cytogenetic studies it became necessary to provide for the training of professional staff with a background in genetics, cytology, and cell biology. A number of graduates, from the Department of Genetics in Jerusalem, has contributed to the further growth and spread of human cytogenetics all over the country.

Since the early 1960 s other medical centres have begun human cytogenetic studies and today 10 laboratories are actively engaged in studies using peripheral blood for clinical cases and bone marrow and solid tumours in malignancies. Prenatal cytogenetics using amniotic cells is performed in five centres, while chorionic villus placental and cord blood sampling are performed in selected centres.

Areas of special scientific interest in human cytogenetics include the chromosome breakage syndrome ataxia telangiectasia. ${ }^{2122}$ The finding of a clastogenic $^{23}$ factor in the amniotic fluid of an affected patient opened up new possibilities for prenatal diagnosis. ${ }^{24}$ One of the first prenatal diagnoses of Fanconi's anaemia was performed in Jerusalem. ${ }^{25}$ The complex syndrome of $\mathrm{X}$ linked mental retardation with the fragile site at $\mathrm{Xq} 27$ is being studied extensively at the chromatin level. Studies on human meiosis are continuing in Professor Wahrman's laboratory especially in relation to subfertility. ${ }^{26}$ Studies on the sensitivity of spindle fibres to various agents and its relation to meiotic non-disjunction are performed in Professor Avivi's laboratory in Tel-Aviv University. Dr F Shabtai in Hasharon Hospital is specifically interested in the role of fragile sites and heterochromatic regions in the aetiology of malignancies.
A new class of chromosome bands, ' $D$ bands', has been defined on the basis of the sensitivity of human chromosomes to DNAse I. This work ${ }^{27}$ has been done in the laboratory of the late Menashe Marcus.

Analysis of chromosomal aberrations is now entering a new era; molecular analysis using specific probes for chromosome markers (for example, alphoid probes for specific centromeres, $Y$ chromosome specific sequences) will be applied in the Department of Human Genetics, Hadassah Medical Centre in Jerusalem as well as in the Sackler School of Medicine in Tel-Aviv. It is hoped that with these new methods, coupled with the wealth of clinical material, we shall continue to contribute to the advancement of human cytogenetics.

\section{Biochemical genetics}

The study of lysosomal storage disorders in various ethnic groups in Israel shows the unique structure of Israeli society and illustrates some unusual findings in certain Israeli communities which will be outlined here.

The two most frequent storage disorders in Israel are Gaucher's disease and Tay-Sachs disease and this is attributed to the fact that Ashkenazi Jews comprise approximately $50 \%$ of the Israeli Jewish population. However, detailed evaluation of TaySachs patients in Israel showed a high proportion of patients of Jewish Moroccan origin. This fact was further established by a preliminary screening programme among the Moroccan Jewish community in Israel, ${ }^{28}$ the results of which indicated a heterozygote frequency of $1 / 60$, similar to the $1 / 30$ Tay-Sachs carrier frequency among the Ashkenazim, and contrasting with the $1 / 300$ carrier frequency among non-Jews or Jews of other origins. ${ }^{1}$ This finding justifies the current policy of including the Jews of Moroccan origin in the countrywidé screening programme performed in Israel since 1975 for the detection of Tay-Sachs carriers. It is not clear yet whether the Ashkenazi and Moroccan Jews have the same or different mutations in the $\alpha$ chain gene of hexosaminidase. This awaits detailed analysis of the $\sigma$ gene itself in both groups of patients.

In addition to the classic infantile type of Tay- N Sachs disease among Ashkenazi Jews, 15 subjects from this ethnic group with the adult form were reported. ${ }^{29}$ The clinical picture varied among these $\stackrel{0}{\Phi}$ patients, but in all except one central nervous $\stackrel{\Phi}{\mathcal{S}}$ system malfunction was observed. The precise frequency of this phenotype among Ashkenazi Jews 0 is not clear, but it must undoubtedly be rare. $\overrightarrow{\mathbb{D}}$ Biochemical analysis of cultured fibroblasts from $\stackrel{\rho}{\mathbb{Q}}$ adult type patients indicated the existence of a $\frac{\varrho}{0}$ compound heterozygote in the $\alpha$ chain locus, 
consisting of the classic Tay-Sachs mutation with no $\alpha$ chain biosynthesis and a second mutation affecting the association of the remaining $\alpha$ chains with the $\beta$ chains of hexosaminidase.

Israel is characterised by the existence of genetic isolates in Jewish and Arabic communities. These communities are also characterised by a high degree of consanguinity. As expected in these cases a relatively high frequency of genetic disorders is common in each community, but unexpected lysosomal storage disorders comprise a large proportion of the recessive disorders, while these disorders are relatively rare in the general population. The fact that these disorders can be tested biochemically and heterozygotes can usually be unambiguously identified enabled us to conduct screening programmes to assess the frequency of the mutant gene in some of these communities and to identify heterozygous couples and offer them prenatal diagnosis. These programmes have caused a dramatic decrease in the birth of affected children. Two examples are illustrated below.

(1) The Habbanite Jews originate from the city of Haban in the south-east of Saudi Arabia. They immigrated to Israel at the beginning of the 1950s and still constitute a closed community with a high degree of consanguinity. Late infantile metachromatic leucodystrophy (MLD) occurs in this community with a high frequency. ${ }^{30}$ MLD is a neurodegenerative lysosomal storage disorder, caused by deficiency of sulphatide sulphatase. The life expectancy of the late infantile variant is six to eight years. Biochemical diagnosis and detailed examination of medical records of Habbanite children who died during the last 25 years indicated the occurrence of one MLD patient in every 75 live births compared to $1 / 40000$ in the general population. Screening programmes for the detection of MLD heterozygotes in this community indicated a carrier frequency of $18 \%$, which is in good agreement with the patient data. Couples where both spouses are MLD heterozygotes have been identified and prenatal testing is offered to these couples.

(2) A similar phenomenon was seen in a Druze community in the north of Israel. This community is also characterised by a high degree of consanguinity. Seven patients with Krabbe's disease were recently diagnosed in this population. ${ }^{31}$ Krabbe's disease is a severe neurodegenerative lysosomal storage disorder caused by deficiency of galactocerebrosidase. Life expectancy is one to two years. Genetic analysis of these families indicated a heterozygote frequency for the Krabbe gene of $1 / 150$ among the Druze compared to $1 / 100000$ in the general population.

These two examples illustrate the potential which appropriate medical services can achieve, namely the prevention of the birth of children affected with severe, incurable disorders by operating proper screening programmes and parallel education of the relevant population. This depends, of course, on the availability of reliable laboratory assay techniques for the detection of heterozygotes and affected fetuses.

Hunter's syndrome (mucopolysaccharidosis II) occurs with a relatively high frequency in the Jewish population in Israel compared to other western populations, particularly among the Ashkenazi Jews. ${ }^{32}{ }^{33}$ Genetic analysis of Ashkenazi families in Israel with Hunter's syndrome patients indicated the absence of new mutations, which is expected in $\mathrm{X}$ linked disorders such as Hunter's syndrome. While approximately one-third of Hunter's syndrome patients in non-Jewish populations is thought to result from new mutations, all the Hunter's patients' mothers in the Ashkenazi families were identified as Hunter heterozygotes and so were the maternal grandmothers when this could be tested. Furthermore, in all the Ashkenazi families with Hunter's syndrome patients, a clear selection in favour of the Hunter gene was evident, ${ }^{34}$ so that an unusually high proportion of family members of these patients were either heterozygous females or affected males. The cause of this phenomenon has not been elucidated yet and could stem from heterozygote advantage, or from pre- or postzygotic selection. Whatever the cause, this phenomenon explains the high frequency of Hunter's syndrome in the Jewish population.

Most of the carriers of Hunter's syndrome in Israel were detected by appropriate enzyme assays. ${ }^{35}$ A new concept developed recently allows early prenatal diagnosis of Hunter's syndrome, in addition to the common procedures such as amniocentesis and chorionic villus sampling. A consistent increase of iduronate sulphate sulphatase, the deficient hydrolase in Hunter's syndrome, in the serum of pregnant women was found only when the fetus was not affected with Hunter's syndrome. ${ }^{36}$ This increase in enzyme activity was noted as early as the eighth to tenth week of pregnancy. On the other hand, when the fetus was affected with Hunter's syndrome, enzyme levels in the serum of the heterozygous mother remained unchanged until the termination of the pregnancy (at least 16 to 20 weeks of pregnancy). In other words, a clear correlation between the increase of enzyme activity in maternal serum and the status of the fetus with regard to Hunter's syndrome could be established. ${ }^{37}$ The source of the enzyme increase during pregnancy is under investigation and could stem either from the fetus itself or from the membranes surrounding it.

Mucolipidosis type IV (MLIV), a recently recog- 
nised lysosomal storage disorder, is found in Ashkenazi Jews with a high frequency. ${ }^{38}$ Though the precise frequency has not been assessed as yet, most of the $\mathbf{4 0}$ patients known today are of Ashkenazi Jewish origin. The disorder is clinically characterised by psychomotor retardation, corneal opacities, and retinal degeneration. It was recently shown that MLIV is involved in the storage of gangliosides, mucopolysaccharides, and phospholipids. ${ }^{3940}$ Ganglioside sialidase is deficient in these patients. ${ }^{41}$ Prenatal diagnosis is performed by electron microscopic observation of the typical inclusion bodies in cultured amniotic fluid cells in MLIV fetuses. ${ }^{42}$

The work described here illustrates the importance of biochemical evaluation of genetic disorders as a powerful tool in preventive medicine. We shall therefore focus our future endeavours in these areas. This should be achieved by identifying the biochemical defect in those genetic disorders where the defect is not characterised as yet, mainly those disorders found in relatively high frequency in specific communities in Israel, such as familial dysautonomia in the Ashkenazi Jews, or albinism and mental retardation in certain Arabic communities. This should lead to the development of reliable assay techniques for unambiguous diagnosis of patients, heterozygotes, and affected fetuses before initiating mass screening in the relevant population.

\section{Molecular genetics}

The use of molecular probes for diagnostic purposes began in Israel in 1981, when a group of molecular biologists at the Medical School of the Hebrew University of Jerusalem and the Department of Haematology at the Hadassah Medical Centre joined forces to introduce the first prenatal diagnosis of thalassaemia and sickle cell anaemia in Israel using globin probes. Since 1985, five additional laboratories in Jerusalem, the Tel-Aviv area, and Beersheva have initiated the use of molecular probes for prenatal diagnosis of cystic fibrosis, Duchenne muscular dystrophy, haemophilia, phenylketonuria, and 21-hydroxylase deficiency, and are preparing for routine diagnosis of the fragile $\mathrm{X}$ syndrome, adult polycystic kidney disease, Huntington's disease, and neurofibromatosis.

Molecular cytogenetics, that is, the analysis of chromosomal aberrations with molecular probes, is in its infancy at the Medical School of Tel-Aviv University. An extensive repository of $\mathrm{X}$ chromosome and autosomal probes has been established for this purpose.

Since the medical genetics community in Israel is small, the periodic meetings of the Israeli Society of
Medical Genetics enable all the members of this community to learn about the progress being made in each laboratory.

Basic research with direct implications for medical genetics is carried out in Israel's universities and at the Weizmann Institute of Science. The Jerusalem group associated with the Departments of Haematology and Cellular Biochemistry at the HadassahHebrew University Medical School has initiated two projects related to haemoglobin disorders: molecular analysis of $\beta$ thalassaemia mutations in the Israel population is being performed using conventional and oligonucleotide probes, ${ }^{43}$ and new vectors for gene therapy of thalassaemia and sickle cell anaemia are being developed. ${ }^{44}$ At the Weizmann Institute of Science, a long term project aimed at the analysis of the portion of chromosome 21 responsible for Down's syndrome was initiated by molecular cloning of the genes for human $\mathrm{Cu} / \mathrm{Zn}$ superoxide dismutase $e^{45-47}$ and liver type phosphofructokinase. Laboratory models for overproduction of superoxide dismutase have been constructed in cultured cells ${ }^{47}{ }^{48}$ and in transgenic mice. ${ }^{49}$. Another group at the Weizmann Institute has recently cloned the gene for human glucocerebrosidase $\mathrm{r}^{50}$ and the probes are being used for the molecular analysis of Gaucher's disease in Israel.

Several groups at Tel-Aviv University are applying 'reverse genetics' to the identification and isolation of human disease genes. A first step towards the molecular cloning of the gene for xeroderma pigmentosum (XP) has recently been made at the Faculty of Life Sciences of this University, where a successful 'correction' of the UV sensitive phenotype of XP cells was achieved by gene transfer. ${ }^{51}$ At the Medical School in Tel-Aviv, the first chromosomal assignment of the locus for Wilson's disease (to chromosome 13) has been made by linkage analysis with classical ${ }^{52}{ }^{53}$ and molecular ${ }^{54}$ markers. The disease gene is being approached by linkage analysis performed with RFLPs using several Israeli families, in collaboration with an American group.

Also in Tel-Aviv University Medical School, regional localisation of the locus for $\mathrm{X}$ linked albinism-deafness syndrome (ALDS) to Xq25-26 was achieved by linkage analysis with RFLPs. ${ }^{55}$ Detailed analysis of the mutations causing phenylketonuria in Israel is under way and has already revealed a single gene deletion which accounts for all the PKU cases among the Yemenite Jews. ${ }^{56} \mathrm{~A}$ group at the Hebrew University of Jerusalem has recently identified the first close association between specific RFLPs at the HLA locus and pemphigus vulgaris. ${ }^{57}$

The large number of rare genetic diseases seen in 
Israel among the various Jewish and non-Jewish communities offers a rich source of investigation for molecular geneticists in this country.

\section{Dermatoglyphics}

The study of dermatoglyphics in Israel began in the late 1950 s with a project analysing the digital patterns of 5000 Jewish males from eight different ethnic groups. ${ }^{58}$ This study showed that Jews differ dermatoglyphically from their former host nonJewish neighbours, but there is a similarity between Jewish finger prints and those of non-Jewish populations from the Middle East. Thus, it was concluded that there exists an Eastern Mediterranean gene pool which involves all of the inhabitants of this area.

This study was the precursor of others on various Jewish groups and a number of isolates such as the Samaritans, Habbanites, the Falasha, and Indian Jews. ${ }^{59-61}$

Because genetic distance between Jewish Israeli populations of different geographical extraction is similar, investigative studies have confirmed that selected dermatoglyphic traits are suitable for calculating interpopulation distance coefficients. 962 Moreover it has been shown that the similarity between different Jewish groups conformed to the findings in diverse Caucasian samples, confirming the discriminating possibilities of palmar dermatoglyphics related to the main human races.

In the 1960s it became clear that patients with certain autosomal and sex chromosomal syndromes (for example, Down's syndrome, XO, XXY, etc) had distinct and characteristic dermatoglyphic patterns. These changes were also noted in fetuses terminated between the 20th and 24th week of gestation. ${ }^{63}$ In addition our studies in Israel showed that these typical dermatoglyphic patterns were superimposed on the existing dermatoglyphic differences between Jews and non-Jews. ${ }^{64}{ }^{85}$ We investigated dermatoglyphic patterns in specific Jewish genetic diseases, like Tay-Sachs disease and familial dysautonomia, plus other inborn errors of metabolism, but did not find any distinct features. On the other hand, we have shown that in some genetic syndromes involving the hands (such as TelHashomer camptodactyly ${ }^{66}$ ) and wrinkly skin syndrome ${ }^{67}$ distinct and even diagnostic changes are present.

An extensive study on the biological significance of two kinds of dermatoglyphic asymmetry, directional and fluctuating, is being performed at TelAviv University. Directional asymmetry can be regarded as a developmentally controlled trait presumably having a genetic basis, while fluctuating asymmetry is thought to result from the inability of the fetus to buffer various stress factors during embryogenesis. There is preliminary evidence to suggest that males are biologically less buffered than females against environmental stress during the prenatal period. ${ }^{68}$

\section{Prenatal diagnosis}

\section{AMNIOCENTESIS}

Amniocentesis is performed in almost every medical centre in Israel. Those peripheral hospitals which do not have cytogenetic laboratories transfer amniotic fluid samples to one of the major regional medical centres. The procedure itself is done by either direct or indirect ultrasonic guidance.

Amniocentesis is free of charge above the age of 37 years (hopefully this will be changed to 35 years in the near future) and also for other indications, such as a previous pregnancy with a severe genetic disease diagnosable by means of amniocentesis. Every amniotic fluid sample is examined for AFP levels in order to detect open neural tube defects, even if the indication for the amniocentesis had nothing to do with a possible neural defect. ${ }^{69}$

Other indications for amniocentesis are fetal sex determination and inherited metabolic diseases, such as Tay-Sachs disease and cystic fibrosis. Owing to the small distances between the regional centres and the good communication between the medical centres in the country it is not necessary for all biochemical tests to be carried out in each of the medical centres. One can choose between the option of sending the candidate to other centres for both amniocentesis and biochemical analysis of the sample and that of sending the sample only.

\section{CHORIONIC VILLUS SAMPLING (CVS)}

In a few of our medical centres, CVS is competing strongly as an alternative to amniocentesis. The indications for the procedure are those for amniocentesis, but also DNA analysis for single gene diseases, such as Duchenne muscular dystrophy, PKU, cystic fibrosis, and haemophilia. It is also possible to use CVS for the enzymatic diagnosis of Tay-Sachs disease and many other inborn errors of metabolism. In Israel, the Sheba Medical Centre has the most experience with CVS having done more than 250 diagnostic procedures with a $2 \cdot 5 \%$ risk of complications.

\section{SERUM $\alpha$ FETOPROTEIN (AFP)}

Serum AFP is examined in almost every pregnancy between the 16th and 19th week of gestation. An AFP concentration of $2.5 \times \mathrm{MOM}$ (multiple of median) is considered as an indication for genetic 
counselling and thorough ultrasonographic evaluation with the possibility of amniocentesis. We have shown ${ }^{70}$ that AFP can be measured as early as the first trimester in maternal serum. There are significant differences in mean AFP values between 10 and 12 weeks' gestation. Four samples analysed for chromosomal abnormality were compared to the values obtained for unaffected pregnancies and were found to be lower.

Lately, much attention has been given to lower levels of AFP possibly indicating that the fetus has Down's syndrome. In cases of levels below $0.5 \times$ MOM, a thorough ultrasonic examination is done to confirm the calculated gestational age. Only then is amniocentesis considered when the risk for Down's syndrome according to the maternal age and weight is greater than 1:250.

\section{MULTIVITAMIN STUDY}

In 1985, Israel joined the international study organised by the Medical Research Council in England for the prevention of neural tube defects (NTD) by preconceptual treatment with vitamins. The Sheba Medical Centre is the Israeli agency and patients who have had at least one NTD affected child/fetus are seen from all over the country for special counselling, in which they are encouraged to join the project.

\section{FETAL BLOOD SAMPLING}

Recently it has become possible to perform fetal blood sampling from the second trimester onwards. The procedure is carried out with ultrasonographic guidance. The indications for the procedure are rapid chromosomal analysis and sex determination as well as biochemical tests in special circumstances.

\section{Genetic counselling and services}

Seven medical genetics centres localised in teaching hospitals affiliated with one of the four medical schools provide genetic counselling in Israel. All genetic centres have laboratory facilities for tissue culture and cytogenetics. Biochemical tests are usually carried out in specialised laboratories according to the type of test. Most centres coordinate the multidisciplinary management of complex syndromes. Genetic counselling is also given before every prenatal diagnostic procedure for genetic conditions.

In general, the approach to genetic counselling in Israel is non-directive. A main concern is the patient's autonomy. In order for this to be respected and maintained it is felt that all relevant information should be disclosed even when ambiguous or con- $\stackrel{\mathbb{P}}{\rightarrow}$ troversial; thus, data and options are presented in an $\underset{\overrightarrow{\vec{S}}}{\overrightarrow{\mathrm{s}}}$ objective way. The same approach is used regarding? genetic counselling in prenatal diagnosis.

Prenatal diagnosis for sex selection unrelated to $X \frac{\overline{\bar{s}}}{\bar{\sigma}}$ linked conditions is strongly opposed by geneticists $ه$ in Israel. The main reasons are opposition to aborting a normal fetus, which is seen as morally ${ }^{\infty}$ unacceptable, and the fact that being of the un- $\vec{O}$ wanted sex is not a medical condition that merits the $\vec{\overrightarrow{ }}$ use of the limited resources and facilities available in ${ }_{\mathcal{O}}$ the genetic centres. On the other hand, prenatal diagnosis is accepted for both maternal anxiety and 0 in women who would oppose abortion. Approxi- N mately 3000 prenatal diagnostic tests are performed $\omega$ per year in laboratories of the genetic centres $\vec{v}$ certified by the Ministry of Health for this purpose. 6 As previously stated, genetic counselling precedes 5 every procedure. The most common reasons for $\vec{T}$ refusing an amniocentesis when recommended by the geneticists are religious objections and maternal $\stackrel{\sim}{\frac{\sim}{3}}$ anxiety. In approximately $10 \%$ of the refusals, the test is not performed because of the husband's $\varnothing$ opposition.

The Institute of Medical Genetics at the Sheba Medical Centre has recently embarked on an extensive programme for evaluating the impact of $\frac{\partial}{0}$ genetic counselling on the processes of coping and decision making. Hopefully, the results of this study $\stackrel{\square}{\triangle}$ will teach us new ways to improve our counselling. $\underset{\vec{F}}{\vec{F}}$ In addition to this undertaking, it is developing its own software for the computerisation of all genetic $\vec{\partial}$ counselling files.

In 1980, a National Program for the Detection and Prevention of Birth Defects was established and $\overline{0}$ sponsored by the Ministry of Health. Besides $\dot{\sigma}$ prenatal diagnosis, it also includes screening of newborn infants and of high risk populations.

Newborn screening tests include phenylketonuria (PKU) and hypothyroidism (Guthrie test and $\mathrm{T} 4 / \mathrm{O}$ TSH). Obviously, newborn infants are also screened for congenital malformations in the nursery. $A$ 음 monitoring system for congenital malformations exists in four hospitals, accounting for approxi- $\sigma$ mately 18000 births per year $(20 \%$ of the births per $N$ year in Israel). Israel is a member of the Inter- N national Clearing House for Birth Defects Monitor- $\sigma$ ing Systems. Recently, a computerised programme for monitoring birth defects, providing genetic $\stackrel{\circ}{=}$ counselling, and performing epidemiological and $\stackrel{\Phi}{+}$ clinical research studies has been developed, under the auspices of the Sackler School of Medicine of ${ }_{0}^{-}$ Tel-Aviv University. The programme is initially $\vec{\Phi}$ being undertaken in the departments of neonato- $\frac{O}{\mathbb{D}}$ logy of three hospitals in the Tel-Aviv area (Hakirya, $\frac{\varrho}{0}$ Beilinson, and Sheba hospitals). 


\section{Boards in Medical Genetics}

The Israel Society for Medical Genetics (ISMG) was formally recognised and its constitution was accepted by the Israel Medical Association (IMA) in November 1986. This confers the status of 'Medical Speciality' and obliges members to conform to the rules of the IMA. The Israel Department of Health can now recognise such specialist status and this has, for the first time, made it possible to request paid posts for medical geneticists, non-medical geneticists, and laboratory workers in the public hospital system by way of the Treasury. A syllabus and programme for postgraduate study for qualifying MD medical geneticists has been submitted to the Scientific Council of the IMA for approval. All future geneticists and genetics units will require accreditation by the ISMG Scientific Council. Preliminary ideas on requirements for certification include: after six years undergraduate training, two to four years of specialist training in any of the other medical specialities recognised by the IMA but with emphasis on longer periods of clinical experience in paediatrics, internal medicine, and obstetrics and gynaecology; two years of clinical genetics in an approved genetics unit; six months of basic science training in a medical genetics laboratory; and theoretical requirements in classical genetics, cytogenetics, biochemical genetics, molecular biology, teratogenesis, clinical syndromology, and genetic counselling have been delineated. Preparation for a final theoretical examination will be in the form of formal postgraduate courses to be given at the TelAviv and Jerusalem Medical Schools.

\section{Conclusions}

Three historical events set the stage for the flourishing of human genetic studies in Israel: (1) the establishment of the modern State of Israel in 1948 , (2) the subsequent mass Jewish immigration to the country from all parts of the world, and (3) the newly emerging discipline of medical genetics. For approximately the past four decades Israeli physicians and human geneticists have been studying genetic polymorphisms and diseases not only in the Jewish but also the non-Jewish communities of Israel. As a result of these efforts a wealth of information has been amassed. Regarding the Jewish communities, population studies have shown that, apart from a few exceptions, most of the communities differ markedly from their former nonJewish host populations. Studies on genetic diseases in Jews have shown that each of the major Jewish groups (Oriental, Sephardi, and Ashkenazi) for the most part have their own distinct and characteristic disorders.
The Israeli genetic community has been stimulated, not only by its plethora of material but also by the current advances being made in all phases of human genetic studies, to continue to increase its knowledge of genetic diseases and population differences and similarities, and also to improve the care of all its people who suffer from genetic diseases. A brief account of our current activities has been presented in this review. Just as few would have predicted 40 years ago the scientific advances that have taken place in the sphere of human genetics, so we shall be surprised as to the tremendous progress that will be made in the next 40 years that will result in better health for all mankind.

Supported in part by grants (to RMG) from the National Foundation for Jewish Genetic Diseases and LA-CO Industries in the USA. The authors are grateful to Mrs Ruth Grossman for her secretarial assistance.

\section{References}

1 Goodman RM. Genetic disorders among the Jewish people. Baltimore: Johns Hopkins University Press, 1979:45-67.

2 Goodman RM. A perspective on genetic diseases among the Jewish people. In: Goodman RM, Motulsky AG, eds. Genetic diseases among Ashkenazi Jews. New York: Raven Press, 1979:1-17.

${ }^{3}$ Goldschmidt E, ed. The genetics of migrant and isolate populations. New York: Williams and Wilkins, 1963:1-396.

4 Ramot B, Adam A, Bonne B, Goodman RM, Szeinberg A, eds. Genetic polymorphisms and diseases in man. Sheba International Symposium. Isr J Med Sci 1973;9:1129-533.

5 Bonne-Tamir B, Bodmer JG, Bodmer WF, et al. HLA polymorphisms in Israel: an overall comparative analysis. Tissue Antigens 1978;11:235-50.

6 Bonne-Tamir B, Karlin S, Kennet R. Analysis of genetic data on Jewish populations. I. Historical background, demographic features and genetic markers. Am J Hum Genet 1979;31:324-40.

${ }^{7}$ Karlin S, Kebett R, Bonne-Tamir B. Analysis of biochemical data of Jewish population. II. Results and interpretations of heterogeneity indices and distance measures with respect to standards. Am J Hum Genet 1979;31:341-65.

8 Steinberg AG, Bonne-Tamir B. Gm and Inv allotypes among Lybian and Ashkenazi Jews and Armenians. Hum Genet 1980;55:391-5.

9 Micle S, Kobliansky E. Dermatoglyphic distances between Israeli Jewish population groups of different geographic extraction. Hum Biol 1985;57:97-111.

10 Cohen T, Levene C, Yodfat T, et al. Genetic studies on Cochin Jews in Israel (1). Population data, blood groups, isoenzymes and HLA determinants. Am J Med Genet 1980;6:61-73.

11 Steinberg A, Levene C, Yodfat Y, et al. Genetic studies on Cochin Jews in Israel (2). 2GM and Inv data-polymorphisms for $\mathrm{GM}^{3}, \mathrm{GM}^{1,17,21}$ without $\mathrm{GM}^{26}$. Am J Med Genet 1980;6:75-81.

12 Bonne-Tamir B, Gross Y, Ashbel S, et al. Genetic polymorphisms among Ethiopian Jews in Israel. Gene Geography 1987;1: $1-8$.

13 Bonne-Tamir B, Johnson MJ, Natali A, et al. Human mitochondrial DNA types in two Israeli populations: a comparative study at the DNA level. Am J Hum Genet 1986;38:341-51.

14 Bonne-Tamir B. The Samaritans: a living ancient isolate. In: 
Eriksson AW, Forsius HR, Nevallina HR, Workman PL, Norico RK, eds. Population structure and genetic disorders. London: Academic Press, 1980:27-41.

15 Goodman RM. Genetic disorders among the Jewish people. Baltimore: Johns Hopkins University Press, 1979:1-493.

${ }^{16}$ Goodman RM, Motulsky AG, eds. Genetic diseases among Ashkenazi Jews. New York: Raven Press, 1979:1-440.

17 Wahrman J, Zahavi A. Intrageneric difference in chromosome numbers of spiny mice (Rodentia: Murinae). Bull Res Counc Israel 1953;3:265.

18 Wahrman J, Berant M, Jacobs J, et al. The oral-facial-digital syndrome: a male lethal condition in a boy with $47 / \mathrm{XXY}$ chromosomes. Pediatrics 1966;37:812-21.

19 Wahrman J, Fried K. The Jerusalem prospective newborn survey of mongolism. Ann NY Acad Sci 1970;171:341-60.

20 Wahrman J, Goitin R, Richler $\mathrm{C}$, et al. The mongoloid phenotype in man is due to trisomy of the distal pale G-band of chromosome 21. Chromosomes Today 1976;5:241-8.

${ }^{21}$ Cohen MM, Sagi M, Ben-Zur Z, et al. Ataxia-telangiectasia: chromosomal stability in continuous lymphoblastoid cell lines. Cytogenet Cell Genet 1979;23:44-52.

22 Shiloh Y, Tabor E, Becker Y. The response of ataxiatelangiectasia homozygous and heterozygous skin fibroblasts to neocarzinostatin. Carcinogenesis 1980;3:815-29.

23 Shaham M, Voss R, Cohen MM. A diffusable clastogenic factor in ataxia-telangiectasia. Cytogenet Cell Genet 1980;27:155-61.

${ }^{24}$ Shaham M, Voss R, Becker Y, et al. Prenatal diagnosis of ataxia-telangiectasia. J Pediatr 1982;100:134-7.

${ }^{25}$ Voss R, Kohn G, Shaham M, et al. Prenatal diagnosis of Fanconi anemia. Clin Genet 1981;20:190-5.

${ }^{26}$ Rosenmann A, Wahrman J, Richler C, et al. Meiotic association between the $\mathrm{XY}$ chromosomes and unpaired autosomal elements as a cause of human male sterility. Cytogenet Cell Genet 1985;39:19-29.

27 Kerem B, Goitin R, Diamond G, et al. Mapping of DNase I sensitive regions or mitotic chromosomes. Cell 1984;38:493-9.

28 Vecht J, Zeigler M, Segal M, et al. Tay-Sachs disease among Moroccan Jews. Isr J Med Sci 1983;19:67-9.

${ }^{29}$ Navon R, Argov Z, Frisch A. Hexosaminidase A deficiency in adults. Am J Med Genet 1986;24:179-96.

30 Zlotogora J, Bach G, Barak Y, et al. Metachromatic leukodystrophy in the Habbanite Jews: high frequency in a genetic isolate and screening for heterozygotes. Am J Hum Genet 1980;32:663-9.

31 Zlotogora J, Regev $\mathbf{R}$, Zeigler $\mathbf{M}$, et al. Krabbe disease: increased incidence in a highly inbred community. Am J Med Genet 1985;21:765-70.

${ }^{32}$ Schaap T, Bach G. Incidence of mucopolysaccharidoses in Israel: is Hunter disease a "Jewish disease"? Hum Genet 1980;56:221-3.

33 Young ID, Harper PS, Archer IM, et al. A clinical and genetic study of Hunter's syndrome. 1 Heterogeneity. J Med Genet 1982;19:401-7.

34 Zlotogora J, Schaap T, Zeigler M, et al. Hunter syndrome among Ashkenazi Jews in Israel: evidence for prenatal selection favoring the Hunter allele. Hum Genet 1985;71:329-32.

35 Zlotogora J, Bach G. Heterozygote detection in Hunter syndrome. Am J Med Genet 1984;17:661-5.

36 Bach G, Eisenberg F, Cantz M, et al. The defect in the Hunter syndrome: deficiency of sulfoiduronate sulfatase. Proc Natl Acad Sci USA 1973;70:2134-8.

37 Zlotogora J, Bach G. Hunter syndrome: prenatal diagnosis in maternal serum. Am J Hum Genet 1986;38:253-60.

38 Berman ER, Livni N, Shapira E, et al. Congenital corneal clouding with abnormal systemic storage bodies: a new variant of mucolipidosis. J Pediatr 1974;84:519-26.

39 Bach G, Cohen MM, Kohn G. Abnormal ganglioside accumulation in cultured fibroblasts from patients with mucolipidosis IV. Biochem Biophys Res Commun 1975;66:1483-90.

40 Bach G, Zeigler M, Kohn G. Mucopolysaccharide accumulation in cultured skin fibroblasts derived from patients with mucolipidosis IV. Am J Hum Genet 1977;29:610-8.

41 Bach G, Zeigler M, Schaap T, et al. Mucolipidosis IV: gangliaside sialidase deficiency. Biochem Biophys Res Commun 1979;90:1341-7.

${ }^{42}$ Kohn G, Livni N, Ornoy A, et al. Prenatal diagnosis of mucolipidosis IV by electron microscopy. J Pediatr 1977;90: 62-6.

${ }^{43}$ Oppenheim A, Karsai A, Treisman R, et al. Beta-thalassemia: है analysis of mRNA precursors of a mutant globin gene with defective splicing using peripheral blood nucleated RBC. Hemoglobin 1986;10:573-86.

44 Oppenheim A, Peleg A, Fibach E, et al. Efficient introduction of plasmid DNA into human hemopoietic cells by encapsidation as SV40 pseudovirus. Proc Natl Acad Sci USA 1986;83:6925-9.

45 Levanon D, Lieman-Hurwitz J, Dafni N, et al. Architecture and anatomy of the chromosomal locus in human chromosome 21 encoding $\mathrm{Cu} / \mathrm{Zn}$ superoxide dismutase. $E M B O J$ 1985;4:77-84.

46 Danciger E, Dafni N, Bernstein $\mathrm{Y}$, et al. Human $\mathrm{Cu} / \mathrm{Zn}$ superoxide dismutase gene family: molecular structure and characterization of four $\mathrm{Cu} / \mathrm{Zn}$ superoxide dismutase-related pseudogenes. Proc Natl Acad Sci USA 1986;83:3619-23.

47 Groner Y, Elroy-Stein O, Bernstein Y, et al. Molecular genetics of Down's syndrome: over expression of transfected human $\mathrm{Cu} / \mathrm{Zn}$ superoxide dismutase gene and the consequent physiological changes. Cold Spring Harbor Symp Qual Biol 1987;51: 381-6.

48 Elroy-Stein O, Bernstein Y, Groner Y. Overproduction of human $\mathrm{Cu} / \mathrm{Zn}$ superoxide dismutase in transfected cells: extenuation of paraquat-mediated cytotoxicity and enhancement of lipid peroxidation. $E M B O J$ 1986;5:616-22.

49 Epstein CJ, Avraham KB, Lovett M, et al. Transgenic mice increased $\mathrm{Cu} / \mathrm{Zn}$ superoxide dismutase activity: an animal model of dosage effects in Down's syndrome. Proc Natl Acad Sci USA 1987;84:8044-8.

${ }^{50}$ Reiner $\mathrm{O}$, Wilder S, Givol D, et al. Efficient in vitro and in vivo expression of human glucocerebrosidase cDNA. DNA 1987;6: $101-8$.

51 Teitz T, Naiman T, Avissar S, et al. Complementation of the UV-sensitive phenotype of a xeroderma pigmentosum human cell line by transfection with a cDNA clone library. Proc Natl Acad Sci USA 1987;84:8801-4.

52 Frydman M, Bonne-Tamir B, Farrer LA, et al. Assignment of the gene for Wilson disease to chromosome 13: linkage to the esterase D locus. Proc Natl Acad Sci USA 1985;82:1819-21.

${ }^{53}$ Bonne-Tamir B, Farrer LA, Frydman M, et al. Evidence for linkage between Wilson disease and esterase $D$ in three kindreds. Genet Epidemiol 1986;3:201-9.

54 Bowoock AM, Farrer LA, Cavalli-Sforza LL, et al. Mapping the Wilson disease locus to a cluster of linked polymorphic markers on chromosome 13. Am J Hum Genet 1987;41:27-35.

55 Litvak G, Sandkuyl L, Ott J, et al. Localization of X-linked albinism deafness syndrome to $\mathrm{Xq}$ by linkage with DNA markers. Cytogenet Cell Genet (in press).

56 Avigad S, Cohen BE, Shiloh Y. A specific deletion with the phenylaline hydroxylase gene is common to most Yemenite Jewish phenylketonuria patients. Am J Hum Genet 1987;41: 205A.

57 Szafer F, Brautbar C, Tzfoni E, et al. Detection of disease specific restriction fragment length polymorphism in pemphigus vulgaris linked to the DQwl and DQw3 alleles of the HLA-D region. Proc Natl Acad Sci USA 1987;84:6542-5.

${ }^{58}$ Sacks L, Bat-Miriam M. The genetics of Jewish populations. I. Fingerprint patterns in Jewish populations in Israel. Am J Hum Genet 1957;2:117-26.

59 Bat-Miriam M, Adam A. A survey of some genetical characters in Ethiopian tribes. X. Fingerprint patterns. Am J Phys Anthropol 1962;20:202-4.

60 Bonne-Tamir B, Ashbel S, Tal A. The Habbanite isolate. Hum Hered 1971:21:478-92. 
${ }^{61}$ Bonne-Tamir B, Roberts DF, Cooper E. Digital dermatoglyphics of Samaritans. Hum Hered 1982;32:335-43.

62 Katznelson BMM, Ashbel S. Dermatoglyphics of Jews. Z Morphol Anthropol 1973;65:14-28.

${ }^{63}$ Katznelson BMM, Goldman B. Fetal dermatoglyphics. Clin Genet 1982;21:237-42.

${ }^{64}$ Katznelson BMM. The dermatoglyphics of Jewish. XXY. Klinefelter and Turner patients. In: Bartsocas CM, ed. Progress in dermatoglyphic research. New York: Alan R Liss, 1982: 435-49.

${ }^{65}$ Katznelson BMM. The dermatoglyphics of Jewish Down patients. In: Bartsocas CM, ed. Progress in dermatoglyphic research. New York: Alan R Liss, 1982:335-52.

${ }^{66}$ Goodman RM, Katznelson BMM, Manor A. Camptodactyly: occurrence in two genetic syndromes and its relationship to other syndromes. J Med Genet 1972;9:203-12.

${ }^{67}$ Gazit E, Goodman RM, Rotem Y. The wrinkly skin syndrome: a new heritable disorder of connective tissue. Clin Genet 1972;4:186-93.

${ }^{68}$ Livshits G, Kobyliansky E. Dermatoglyphic traits or possible markers of developmental processes in humans. Am J Med Genet 1987;26:111-22.

${ }^{69}$ Barkai G, Mashiah S, Serr DM, et al. Antenatal diagnosis of congenital neural tube defects by alpha-fetoprotein in amniotic fluid. Harefuah 1981;8:361-4.

${ }^{70}$ Barkai G, Chaki R, Pariente C, et al. First trimester alphafetoprotein levels in normal and chromosomally abnormal pregnancies. Lancet 1987;ii:389.

Correspondence to Professor R M Goodman, Institute of Medical Genetics, The Chaim Sheba Medical Centre, Tel-Hashomer 52621, Israel. 